\title{
Nature rules hidden in the biomimetic wave energy converters
}

\author{
H. Zhang ${ }^{\text {a, b }}$, G. A. Aggidis ${ }^{\text {b,* }}$ \\ ${ }^{a}$ Naval Architecture and Electromechanical Engineering College, Zhejiang Ocean University, Zhoushan, Zhejiang, P.R.China, \\ 316022 \\ ${ }^{\mathrm{b}}$ Lancaster University Renewable Energy Group and Fluid Machinery Group, Engineering Department, Lancaster LA14YW, \\ United Kingdom \\ ( ${ }^{*}$ Corresponding author: e-mail: G. A. Aggidis@lancaster.ac.uk)
}

\begin{abstract}
Some animals and plants have special functions and structures. They are the result of biological evolution and Nature's ideas. The question to answer is how to use these biomimetic ideas to design the next generation of wave energy converters. In this paper, the characteristics of the existing wave energy converters are analysed using biomimetic ideas and then the design rules hidden in them are established. First, the characteristics of wave energy are introduced. Next, the state of the art and methods of energy extraction by the wave energy converters are analysed. Then based on the introduction of the biomimetic design knowledge, the biomimetic features, principles and characteristics of the wave energy converters are explained. Lastly the association rules hidden in the biological features and engineering features are mined based on the Apriori algorithm. These rules will assist the development of the next generation of biomimetic wave energy converters and provide future research trends.
\end{abstract}

Keywords: Wave energy; Wave energy converters; Association rules; Rules mining; Biomimetic design.

\section{Introduction}

With significant increase on the global energy needs, the development and utilization of sustainable energy becomes more urgent. Ocean waves have the huge potential to provide a completely sustainable source of energy, which can be captured and converted into electricity by wave energy converters (WECs). Unfortunately there are a number of barriers on the road to developing and commercializing WECs. The main reason for this relates to the number of requirements for WECs, including survivability[1], stability[2], eco-friendliness[3] and economics[4] amongst others that are still difficult to meet. Thus, we require to find new ways of solving these problems.

Biomimetic design can trigger design inspiration and provide additional ideas for new potential designs[5]. Using biomimetic design methods in engineering design we might be able to achieve new, novel and unexpected design results[6,7]. Thus the use of biomimetic design methods and principles has the potential to become an additional tool for the development of novel WECs.

In this paper, the characteristics of wave energy are summarized in section 2 and the methods of energy extraction of the existing WECs are analysed in section 3 . Section 4 introduces the basic concepts and classification of the biomimetic designs, whilst the bionic characteristics, working principles and characteristics of the biomimetic WEC devices are analysed in more detail in section 5. In section 6 , the association rules hidden in the biological features and engineering features are mined based on the Apriori algorithm. Finally, the insights and conclusions are drawn and synthesized.

\section{Wave energy}

Wave energy usually means ocean wave energy. It is one of the renewable energy sources in the world and becoming the highlight of the coastal countries. These countries vigorously carry out wave energy conversion studies[8], especially in the United Kingdom with the largest investment and the most significant research outputs[9]. According to the data from the EMEC[10], the number of wave energy devices in each country has been calculated and shown in Tab.1. We can see clearly from Table 1, Europe and the United States have made great progress in the development and utilization of wave energy and developed a number of wave energy conversion devices.

Wave energy is a true clean and renewable energy source following the solar energy and wind energy. Wave power generation has a number of advantages, including large energy storage, high energy density and minimal impact on the environment. At the same time, wave energy has uncertainties like being oscillatory and irregular[2]. Wave parameters, like wavelength, period, frequency, speed, steepness and crest height, do vary with different time, space, climate and other factors, thus causing the corresponding wave energy to vary. As wave resource has high density, thus the forces on the mechanisms and the related construction costs increase accordingly. Therefore, most WEC devices are restricted to work in specific ranges of frequencies and directions[11].

Table 1 Percentage of a total of 170 WECs in different countries

\begin{tabular}{|l|l|l|l|l|l|l|l|}
\hline Country & $\boldsymbol{\%}$ & Country & $\mathbf{\%}$ & Country & $\boldsymbol{\%}$ & Country & $\%$ \\
\hline USA & 24.1 & Portugal & 2.4 & Germany & 1.2 & Greece & 0.6 \\
\hline UK & 18.2 & Canada & 1.8 & Belgium & 1.2 & Chile & 0.6 \\
\hline Norway & 8.8 & India & 1.8 & Japan & 1.2 & Singapore & 0.6 \\
\hline Denmark & 7.1 & China & 1.8 & France & 1.2 & Korea & 0.6 \\
\hline Spain & 5.9 & Italy & 1.2 & Israel & 1.2 & Slovenia & 0.6 \\
\hline Australia & 4.7 & $\begin{array}{l}\text { Hong } \\
\text { Kong }\end{array}$ & 1.2 & Turkey & 0.6 & Wales & 0.6 \\
\hline Ireland & 3.5 & Russia & 1.2 & Mauritius & 0.6 & $\begin{array}{l}\text { New } \\
\text { Zealand }\end{array}$ & 0.6 \\
\hline Sweden & 2.4 & Finland & 1.2 & Brazil & 0.6 & & \\
\hline
\end{tabular}

The challenge in the development of WECs is to design a device that can work normally on the worst storms, at the same time produce amount of energy meeting the design 
requirements. So far WECs have been too costly and financially demanding to promote commercial harvesting[12]

\section{Wave energy converters (WECs)}

\subsection{The current state of the WECs}

WECs can harness energy from waves and convert it into useful power. They utilize the circular movement of waves to turn a turbine or a generator, or convert the motion directly to electricity[13]. In order to reduce costs and improve availability, significant research has been carried out that includes the following aspects:

- Energy extraction. Research has been carried out on designing and optimising energy extraction in order to improve the efficiency of energy extraction. A dualchannel WEC[14] and a cycloidal WEC[15] were designed to produce a steady stream of electricity in unidirectional irregular deep ocean waves. On the other hand, efficiency of the device in power absorption, energy capturing, energy extraction and energy exchange were optimised by using the biomimetic design methods[16].

- $\quad$ Power Take Off (PTO)/turbine. Some researchers focus on the development of novel PTO systems. A drag type water turbine[17] and a novel radial self-rectifying air turbine[18] were designed for use in WEC. Other researches focus on the conversion of the WEC motion into usable electricity by the power take-off system. The optimization of PTO effective parameters has been presented using biomimetic algorithm to optimise the power output and energy transfer[19].

- Energy modelling research. There are some mathematical models provided for designing point absorbers WEC, oscillating water column WEC and oscillating wave surge converters[20] to generate electricity from ocean-sea waves. These numerical models can be used to calculate the hydrodynamic responses in waves and the power produced.

- Optimisation, operation, and control systems of arrays. Relations between the hydrodynamic coefficients are derived and applied for optimising the power output of the wave farm[21].

- Wave energy testing facilities. Some experimental studies and test facilities design[22] are carried out to study the movement and energy conversion performance of the WEC with swing arms and floaters.

- Mooring system. Some new mooring systems for floating devices adapted to the wave energy have been developed to increase safety or better interaction with the converter[23].

\subsection{Mimicking the single feature}
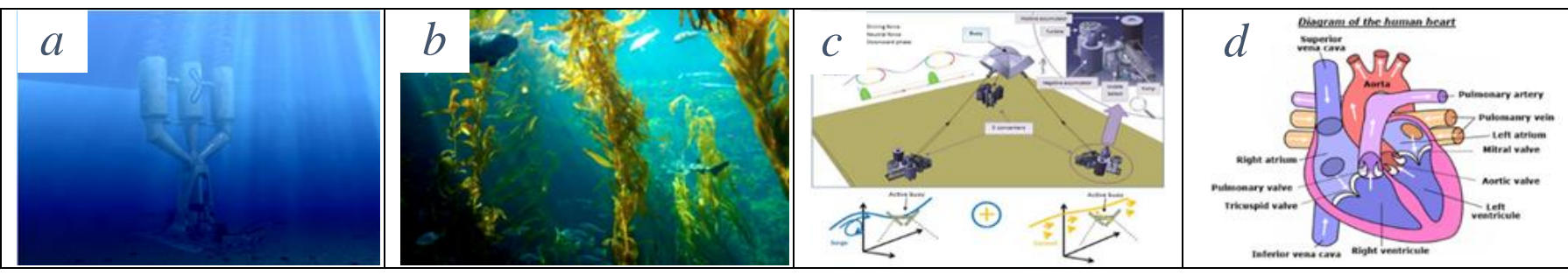
important role in the development of WECs and is used for designing and optimisation of devices. Moreover, energy extraction research receives more attention. A WEC with low cost, high efficiency, high survivability and being ecofriendly provides a novel solution for energy extraction.

\subsection{Methods of energy extraction}

Different devices use a number of various methods for extracting wave energy. Hence, there is a wide variety of methods for extracting wave energy. The common methods for energy extraction include heave, pitch, surge, overtopping and oscillating water column. As new ideas continue to develop, new methods for energy extraction are being explored.

Thus for the development of WECs, it is very important to extract energy from ocean waves with low cost and high economic yield. To produce WECs meeting these requirements there is not an easy design approach available to date, but nature could provide assistance to solve this problem, using the biomimetic design method.

\section{Biomimetic design}

Biomimetics is the imitation of models, systems, and elements of nature for solving complex human problems[6]. Biomimetic design can be applied to inspire engineering innovation with help from different analogies based on the function, principle, shape, structure, material, process, organizational strategy and behaviours of the various biological entities. It is publicly viewed as an innovative and novel solution to actual engineering problems and has been applied to develop renewable energy generation techniques[24].

There are two approaches to support biomimetic design. The first approach is solution driven where an interesting biological phenomenon inspires the exploration of potential applications. The second approach is problem driven where a given problem stimulates the search for biological analogies that could help solve the problem and is more widely applied to design and optimise the WECs[25].

\section{Bio-inspired WEC}

To reduce the WEC's cost and increase the overall efficiency of the device, some developers design novel WECs inspired by biological phenomena. This section details examples that illustrate the use of a general biomimetic design method. In addition to the working principle of the various devices, the technical characteristics of the device are analysed. The advantages and disadvantages of the devices are also highlighted. 


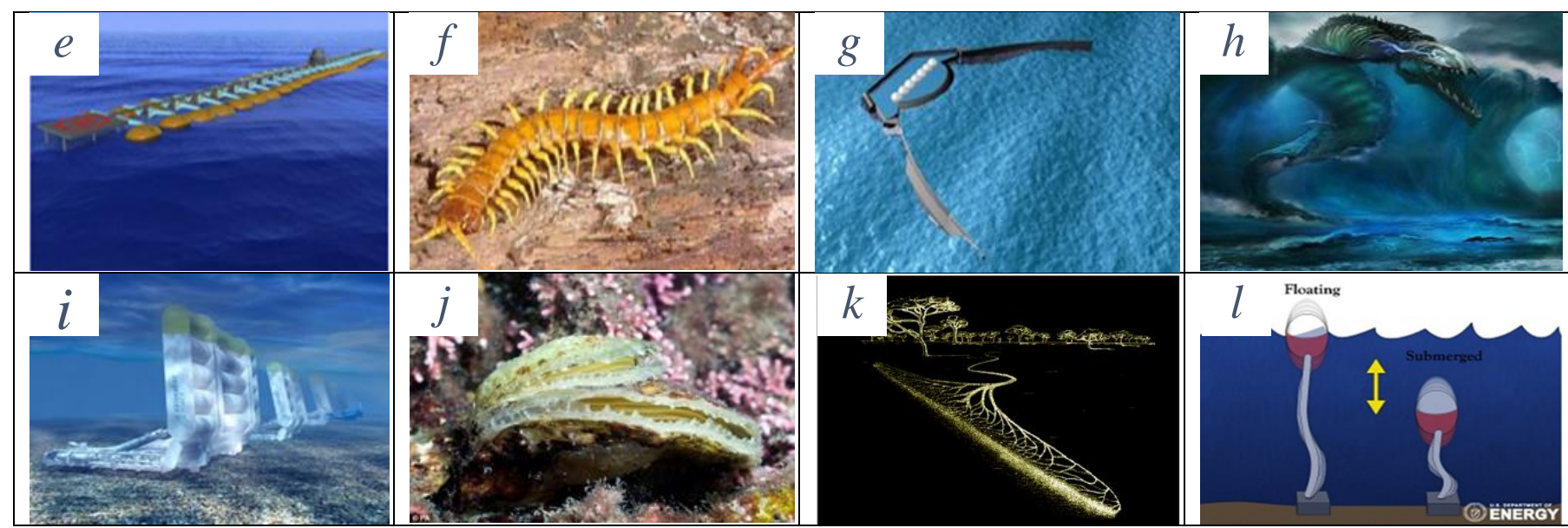

Fig.1. Mimicking The Single Feature. a, bioWAVE WEC[26]. b, Kelps[27]. c, Sea Heart WEC[16]. d, The human heart[28]. e, Centipod WEC[29]. f, Centipod[30]. g, Wave Dragon WEC[31]. h, Dragon in the mythology[32]. i, Oyster WEC[33]. j, Oyster[34]. k, Ant Colony Optimization[35]. 1, Point absorber buoy[36]

\subsubsection{Mimicking the function - bioWAVE}

The bioWAVE is a wave power system inspired by the moving and reorienting of kelp plants (Fig. 1a). Kelps are large seaweeds belonging to the brown algae and grow in low-temperature shallow oceans. Kelps consist of blades, the handle and the holdfast. The blades are flat or leaf-like structures and their tips are gradually narrowed (Fig. 1b). They are usually 2 to 5 meters long, 20 to $30 \mathrm{~cm}$ wide with thin edge. The blades originate from elongated stem-like structures, the stipes. The holdfast is a root-like structure and anchors the kelp to the substrate of the ocean[27].

Not only can the bioWAVE move back and forth like kelps, but also lay flat on the sea floor during storm conditions. This new underwater power generator that was developed by an Australian company is equipped with all these features. The bioWAVE is fixed or anchored by a triangular foundation to the ocean floor similar to kelps. This makes it capable of capturing the widest and deepest swath of the wave energy at a depth of 30 metres. When waves move, the blades are pushed back and forth. The column is made to move back and forth relative to the foundation. The movement would spin permanent magnet motors and convert the low-speed high-torque oscillation into high-speed low-torque rotation.

The bioWAVE WEC has some specific features, such as high conversion efficiency, low-cost installation, is ecofriendly and has high survivability. But the control variables, such as the blade spacing, ballasting and power capture need to be adjusted accordingly. It is very important for the device to select the suitable water depths to avoid any potential installation problems and decreasing wave power capture.

\subsubsection{Mimicking the principle - Sea Heart}

The Sea Heart WEC is inspired by the human heart and with discharge of a water volume at low pressure but with a high flow rate (Fig. 1c). The human heart is pear-shaped and is divided into four chambers, such as upper left and right atria, lower left and right ventricles. The heart can pump blood through the blood vessels of the circulatory system. Blood provides the body with oxygen and nutrients, as well as assists in the removal of metabolic wastes (Fig. 1d).
The Sea Heart WEC is designed to a semi-submerged buoy cage generator using the wave's water mass displacement associated with the marine surface current. It is composed of the buoy and three energy convertors. The buoy is used to extract the mechanical energy form the wave and current movement that gives a moving and a restraining force. This displacement is transmitted by hawsers to the convertor system located on the sea floor. Then the energy convertor converts the hydraulic energy under a high flow with low pressure into electrical energy with constant frequency. Depending on the waves and sea current direction and intensity, each converter is able to extract a different amount of energy[16].

The Sea Heart WEC uses hybridization of marine waves and sea current energy sources. It means high flexibility of use, but the stability of electrical energy becomes a problem needed to solve. The Sea Heart WEC is expected to provide a very important and global efficiency $60 \%$ to $70 \%$. But it is disappointing that reports and papers about the Sea Heart WEC are currently not available in the public domain. Thus the general status of the prototype manufacturing and model testing are unknown.

\subsubsection{Mimicking the structure - Centipod}

The Centipod WEC is a floating offshore WEC. It is a stable and multiple point absorber platform with 30 -foot long line buoys which resemble the legs of the centipede (Fig. 1e). Centipedes are arthropods belonging to the class Chilopoda. They have many legs that are bear at most of the body segments except for the first segment and the final two segments (Fig. 1f). It is very interesting that each pair of legs is slightly longer than the pair immediately in front of it. This feature ensures that they do not collide with each other while moving swiftly.

But the legs of the Centipod WEC are same size. The centipede looks for food on the land, but the Centipod WEC captures energy in the ocean. The Centipod WEC includes the backbone, buoys, PTO components and mooring lines. Hydrodynamic components are attached to the backbone and buoys[29]. The Centipod WEC generates electricity as its buoys rise and fall, driving generators in the tubular 
backbone structure[37]. Although some work have been completed, the development of a PTO system capable of providing the necessary reactive power for a reactive control scheme such as the Model Predictive Control (MPC) will still need to be undertaken. A hardware unconstrained case and the optimization of MPC algorithm are planned to be explored.

The Centipod WEC is a promising solution and has low environment impact. However, the loads and stresses on the structure need to reduce for better and potentially more economical design.

\subsubsection{Mimicking the shape - Wave Dragon}

The Wave Dragon WEC is a floating slacking-moored wave energy converter (Fig. 1g). It has two large outstretched wave reflector arms like the wings of the dragon. A dragon is a legendary creature typically with a body like a huge lizard, or a snake with two pairs of lizard-type legs, and able to emit fire from its mouth. The European dragon has bat-like wings growing from its back and is often revered as representative of the primal force of nature, religion and the universe. The wave dragon can provoke the huge wave by its large wings in the mythology (Fig. 1h).

The two reflectors of the Wave Dragon WEC cannot be waved to bring out storm and just focus the waves towards a doubly curved ramp. There is a large reservoir used to collect the water run up the ramp and temporarily store it. The water leaves the reservoir through low-head hydro turbines with permanent magnet generators and produces electricity[31] The device was invented by Erik Friis-Madsen[38], and it has been developed with funding support. Significant time and effort has been placed on the design, modelling and testing in order to optimize overtopping, refine hydraulic response, reduce forces on wave reflectors and mooring system, reduce construction costs, maintenance and running costs. These designs have optimized the special elliptical shape of the ramp, and model testing has shown that overtopping increases significantly.

The Wave Dragon WEC is a very simple overtopping wave energy converter. Its ability to be freely up-scaled and adjusted to varying wave heights is its unique advantage. Its operation and maintenance cost is very low, but the energy absorption performance still needs to be independently verified and further research is required on the optimisation of the power production.

\subsubsection{Mimicking the behaviour - Oyster}

The Oyster WEC is a flap-type wave surge converter and is comprised of a hinged deflector, positioned perpendicular to the wave direction (Fig. 1i). It can swing back and forth with the movement of the waves such as oysters opening and closing shells. But the oyster has two shells of different shape. The upper shell is uplift and small. The lower shell is generally attached to the shallow sea objects or seaside reefs and is large and quite flat. The two shells are connected with a resilient ligament (Fig. 1j). Then oyster can open and close for capturing food and breathing[39].
The movement of the Oyster WEC is used to pump highpressure water to shore and drive hydroelectric equipment[40]. The Oyster WEC is also bottom mounted with water depths of 10-20 metres and completely penetrates the water column from the water surface to the seabed. It is a near shore wave energy converter. The preformation of the Oyster WEC would be affected by environment such as the nearshore wave climate, the exploitable resource and the working frequency range[41]. The key design technologies including the nearshore wave energy resource, the power capture characteristics of bottom-hinged flap type oscillators and the hydroelectric power take-off system have been researched.

The Oyster WEC has high survivability. Although the capacity of the individual Oyster is limited owing to wave resource, hydrodynamic and economic constraints, the power stations formed by arrays of clusters and a farm of Oyster units could generate enough energy to apply to thousands homes.

5.1.6. Mimicking the strategy - Ant Colony Optimization algorithm (ACO)

The ant colony optimization algorithm (ACO) is a probabilistic technique aimed to search for an optimal path in a graph (Fig. 1k). The algorithm is initially proposed by Marco Dorigo in 1992 inspired by the behaviour of ants seeking a path between their colony and a source of food[42]. When one ant finds a short path from the colony to a food source, other ants are more likely to follow that path, and positive feedback eventually leads to all the ants following a single path.

ACO is a simulation evolutionary algorithm and has many excellent properties. It is able to search for an optimal solution based on its self-organized autonomous learning capability. It can adapt to changes in real time and has been applied to many optimization problems, ranging from the control of the all-electric PTO to the parameter optimization design of controllers. Now AOC has been applied to optimize the performance of WECs in order to reduce their operating costs and used as a decision support tool for real time wave energy extraction of a point absorber WEC[43] (Fig. 11). The optimal parameter values are provided to the control model within short intervals to respond to the continuously changing of the ocean wave attributes. AOC is not only applied to a particular WEC, but can be applied to most of the WECs.

Now AOC need to be improved further to adapt to different operational environments and different optimized parameters of the WEC.

\subsection{Mimicking the multi-features}




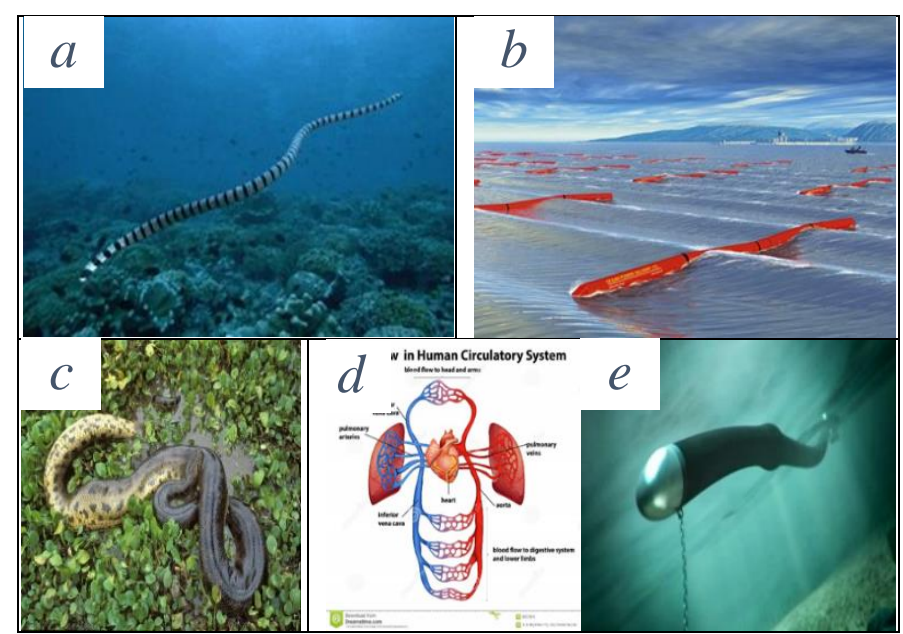

Fig.2. Mimicking the Multi-Features. a, Pelamis[44]. b, Pelamis WEC[45]. c Anaconda[46]. d, Human circulatory system[47]. e, Anaconda WEC[48]

\subsubsection{Mimicking the shape and motion - Pelamis}

The Pelamis WEC was designed by the Ocean Power Delivery Ltd with the help of imitating the shape of the sea snakes. The sea snake is a subfamily of the Cobra family. The former part of the sea snake is small and cylindrical (Fig. 2a). The latter part is slightly flat side as the oar[46]. When swimming in the sea, the sea snake would move like the boat sculls. The sea snakes live in the continental shelf and shallow water around the island. That is rare to stay in the more than 100 meters.

The Pelamis WEC is the first wave-energy machine to generate electricity into the grid[48]. The device is composed of the multiple cylindrical bodies linked by the joints and hinges (Fig. 2b). Its length is more than 180 meters and deployed in water depths over 20 metres[49]. The device is an offshore WEC and can free-float on the sea surface. It would bob up and down or sway right and left with the motion of the waves. At the same time the components of the device would have a relative motion in order to drive the hydraulic pistons to pump fluid and the generator to produce electricity. The survivability and efficiency in power capture or absorption, the novel joint and the control system are emphasised on the design of the Pelamis WEC.

The Pelamis WEC is a moored, floating device of the attenuator type. It can reach $100 \%$ capacity when wavelength matches the pitch of the Pelamis WEC. As the Pelamis WEC's pitch is fixed, the maximum energy can't always be captured when the sea conditions change. And this is a limitation of the Pelamis WEC.

\subsubsection{Mimicking the shape and principle - Anaconda}

The Anaconda WEC has the huge body and swallowing effect like Anacondas. Anacondas are snake-giants and from the largest snakes in the world (Fig. 2c). Their sizes are usually 6-11 metres long and 50-160 kg heavy[46]. They live in tropical juggle and swallow the prey without chewing when they snatch their prey. With the help of alternate movement of the upper and lower jaw, the food will be transported into the stomach.

In addition the Anaconda WEC has a similar working principle to the human blood system. The fact that blood can flow in the soft blood vessels is due to the heart pumping pressure, whilst at the same time, the movement of muscle surrounding blood vessels can squeeze the blood vessels (Fig. $2 \mathrm{~d}$ ). These pressure pulses from the heart are propagating as bulge waves in aortas. The Anaconda WEC captures wave energy with bulge waves propagating like pressure pulses from heart in the blood system.

The Anaconda WEC is a submerged offshore device and about 150 metres long and 7 metres diameter (Fig. 2e). It was invented by Rainey and Farley and used a closed and distensible rubber tube filled with water and aligned with the incoming waves[50]. Pressured by the passing sea waves outside, the bulge waves are excited inside which can drive a turbine generator at the stern for energy production.

The Anaconda WEC is a cost-effective wave energy device owing to its extreme simplicity and the unique durability of rubber. Thus setting out the mathematical model by means of mining and analysing the test data in order to obtain the optimal parameters and improve the performance of the rubber tube would be an urgent research next step.

\section{Mining rules in bio-inspired WEC}

Along with the development of information techniques, the data mining technologies are used to uncover unknown and regular relationships hidden in data warehousing, which are very important to decision making and knowledge acquisition. There are a number of methods for effectively achieving association rules. R. Agrawal et al. proposed the well-known Apriori algorithm[51] for mining frequent itemsets. The method mined large frequent itemsets through the combination and pruning of small frequent itemsets. In this paper, it is used to mine the rules hidden in bio-WECs and to acquire the trend knowledge.

\subsection{Pre-processing bio-WECs}

Some bio-WECs are selected to extract the useful information. These bio-WECs are composed of the WECs that are named using an animal name or they are designed using biological principles. The bio-WECs include some information, such as mimicked types, design type, output power and so on. This information is shown in Tab.2. 


\begin{tabular}{|c|c|c|c|c|c|c|c|c|c|c|}
\hline & Bio-WEC. & Mimicked types. & $\begin{array}{l}\text { Mimicked } \\
\text { objects. }\end{array}$ & $\begin{array}{l}\text { The class of } \\
\text { mimicked } \\
\text { objects [28] }\end{array}$ & Design type (EMEC)[10]. & $\begin{array}{l}\text { Methods of power } \\
\text { extraction .. }\end{array}$ & PTO. & $\begin{array}{l}\text { Maximum output } \\
\text { power (KW) }\end{array}$ & $\begin{array}{l}\text { Mean wave } \\
\text { power(KW/m). }\end{array}$ & Water depths (m) \\
\hline 1. & Anaconda, & Shape, Primciple. & $\begin{array}{l}\text { Anaconda \& } \\
\text { Human Heart. }\end{array}$ & $\begin{array}{l}\text { Reptilian \& } \\
\text { Human. }\end{array}$ & \begin{tabular}{|l} 
Bulge Wave. \\
\end{tabular} & \begin{tabular}{|l|} 
BulgeWave[52]. \\
\end{tabular} & Hydraulic Turbime[52]. & 1000[52,48,53]. & (power(nwmin. & $20[48,53]$ \\
\hline 2. & Penguin. & Motion. & \begin{tabular}{|l|} 
Penguin. \\
\end{tabular} & Aves. & Rotating Mass. & Roll, heave and pitch[55]. & $\begin{array}{l}\text { Limear electrical } \\
\text { generator }[55] \text {. }\end{array}$ & $500[55]$ & \begin{tabular}{|l} 
Unknown. \\
\end{tabular} & Unknown. \\
\hline 3. & OSPREY. & Behaviour. & Osprey.: & Aves.r. & Oscillating Water Column. & $\begin{array}{l}\text { Oscillating Water } \\
\text { Column[57]. }\end{array}$ & Air Turbine[59]. & $2000[54,59,60] \cdot r$ & $50[58]$ & $15-20[58]$ \\
\hline 4. & LIMPET: & Behaviour. & Limpet. & Gastropoda. & Oscillating Water Column. & $\begin{array}{l}\text { Oscillating Water } \\
\text { Column[60]. }\end{array}$ & Air Turbime[6]]. & $500[61,62,63]$ & \begin{tabular}{|l}
$15[62,63]$. \\
.
\end{tabular} & $15[62,63]$. \\
\hline 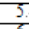 & Might Whale. & \begin{tabular}{|l|} 
Structure. \\
Suts
\end{tabular} & \begin{tabular}{|l|} 
Whale. \\
\end{tabular} & Mammalia, & Overtopping/ Terminator.. & Overtopping $[64]$. & Air Turbime[5]]. & $110[57,65,66]$. & \begin{tabular}{|l}
$15[65,66]$. \\
\end{tabular} & $40[64,65,66]$ \\
\hline 6. & Wave Dragon. & Shape., & \begin{tabular}{|l} 
Dragon. \\
r
\end{tabular} & Virture. & Overtopping/Terminator. & Overtopinging[31]. & Hydraulic Turbine[61]. & $40[31,67]$ & $24[31,6]]$ & $20-30[31,6]]$ \\
\hline 7. & Oyster 800. & \begin{tabular}{|l|} 
Behaviour. \\
\end{tabular} & \begin{tabular}{|l|} 
Oyster. \\
\end{tabular} & Bivaluia, & Oscillating Wave Surge Converter. & \begin{tabular}{|l|} 
Surge[6] \\
\end{tabular} & Hydraulic Motor $[6]]$ & $800[68]$ & \begin{tabular}{|l} 
Unknown. \\
\end{tabular} & $10-15[69]$ \\
\hline 8 & biowave. & \begin{tabular}{|l|} 
Function, motion. \\
\end{tabular} & Kelp. & Phaeosporeal- & \begin{tabular}{|l} 
Osclllating Wave Surge Converter. \\
\end{tabular} & Surge[61], Pitch[71]. & Hydraulic Motor $[61]$ & $1000[70]$ & $50[70]$ & $6-23[70]$ \\
\hline 9 & Centipod. & \begin{tabular}{|l|} 
Structure. \\
\end{tabular} & Centipod. & Chilopoda. & \begin{tabular}{|l|} 
Attenuator. \\
\end{tabular} & Heave[72]. & Hydraulic Motor $[72]$ & Unknown. & \begin{tabular}{|l} 
Unknown. \\
\end{tabular} & Unknown. \\
\hline 10. & Salter Duck. & Shape, Motion. & Duck. & Aves..1 & \begin{tabular}{|l|} 
Attenuator.. \\
\end{tabular} & Pitch[73]. & Hydraulic Motor[73]. & $375[73]$. & \begin{tabular}{|l|l}
$24[73]$ \\
\end{tabular} & $2-30[73]$ \\
\hline 11. & Pelamis (P2). & \begin{tabular}{|l|} 
Shape, Motion. \\
\end{tabular} & Sea Snake. & Repptilia, & \begin{tabular}{|l|} 
Attenuator. \\
\end{tabular} & Pitch, Yaw[ 74$]$. & Hydraulic Motor [61]. & $\begin{array}{l}1000[75] \\
\end{array}$ & $15-40[75]$ & $50-60[75]$ \\
\hline 12 & Duck. & Shape, Motion. & Duck. & Aves.r. & \begin{tabular}{|l|} 
Attenuator. \\
\end{tabular} & Pitch[76] & Hydraulic Motor $[76]$ & $100[59,76]$ & 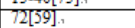 & Unknown. \\
\hline 13. & Sharp Eagle. & \begin{tabular}{|l|} 
Shape. \\
\end{tabular} & \begin{tabular}{|l|} 
Eagle., \\
\end{tabular} & Aves. & \begin{tabular}{|l|} 
Attenuator. \\
\end{tabular} & Pitch [77]., & Hydraulic Motor[77], & \begin{tabular}{|l}
$120[77]$ \\
\end{tabular} & $4[77]$, & $28-30[78]$. \\
\hline 14. & Wavenet(Squid). & \begin{tabular}{|l|} 
Shape. \\
\end{tabular} & \begin{tabular}{|l|} 
Squid. \\
\end{tabular} & Cephalopoda. & \begin{tabular}{|l|} 
Attenuator. \\
\end{tabular} & $\begin{array}{l}\text { Pitch, Roll, Heave, Surge } \\
\text { and sway[79]. }\end{array}$ & Hydraulic Motor $[79]$ & $7.5[79,80]$ & Unknown. & $20-30[80]$ \\
\hline 15 & Seaweed. & Motion. & \begin{tabular}{|l|} 
Seaweed. \\
\end{tabular} & Polyphyletic. & \begin{tabular}{|l} 
Attenuator. \\
\end{tabular} & 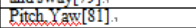 & Hydraulic Motor[81]. & $750[81]$ & Unknown. & $350[81]$ \\
\hline 16. & Jellyfish. & Motion. & \begin{tabular}{|l|} 
Jellyfish. \\
\end{tabular} & Cnidaria. & Point Absorber. & $\begin{array}{l}\text { Heave, Pitch, Surge and } \\
\text { Roll [82]. }\end{array}$ & $\begin{array}{l}\text { Limear electrical } \\
\text { generator }[82] \text {. }\end{array}$ & $600[83]$. & \begin{tabular}{|l} 
Unknown. \\
\end{tabular} & Unknown. \\
\hline 17. & EelGrass. & Behaviour. & EelGrass. & Zosteraceae. & Point Absorber. & \begin{tabular}{|l|} 
Surge[34] \\
\end{tabular} & Hydraulic Turbine[84]. & Unknown. & $\begin{array}{l}\text { Unknown. } \\
\end{array}$ & $2-5[84] \ldots$ \\
\hline 18. & Seaheart. & $\begin{array}{l}\text { Primciple. } \\
\end{array}$ & Human Heart. & Human. & Point Absorber. & Heave Surge[16]. & Hydraulic Motor [16]. & Unknown. & $\begin{array}{l}\text { Unknown. } \\
\text { Unow }\end{array}$ & Unlanown. \\
\hline 19. & Wave Star. & Behaviour, Structure. & Sea Stars.1 & Asteroidea. & \begin{tabular}{|l} 
Point Absorber. \\
\end{tabular} & Heave[S5]. & Hydraulic Motor [85] & $6000[86]$ & \begin{tabular}{|l}
$24[86]$ \\
\end{tabular} & $20-25[85]$ \\
\hline 20. & PSFrog. & Motion. & Frog. & 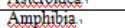 & $\begin{array}{l}\text { Point Absorber. } \\
\end{array}$ & Pitch[87]. & Hydraulic Motor [59]. & $2000[59]$. & 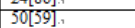 & $40[59]$ \\
\hline 21. & Seadog. & \begin{tabular}{|l|} 
Motion. \\
\end{tabular} & \begin{tabular}{|l|} 
Fur seal.s \\
\end{tabular} & Arctocephalinae. & Point Absorber. & \begin{tabular}{|l} 
Heave[$[88]$. \\
\end{tabular} & Hydraulic Motor [89]., & Unknown. & \begin{tabular}{|l|} 
Unknown. \\
\end{tabular} & $20[54]$ \\
\hline 22. & Oceanstar. & Shape. & Sea Stars.r & Asterozoa. & Horizontal Axis Turbine. & Roll[90]. & Hydraulic Turbine[90]. & Unknown. & Unknown. & Unknown. \\
\hline
\end{tabular}

Table 2 Features of bio-WECs (Continue)

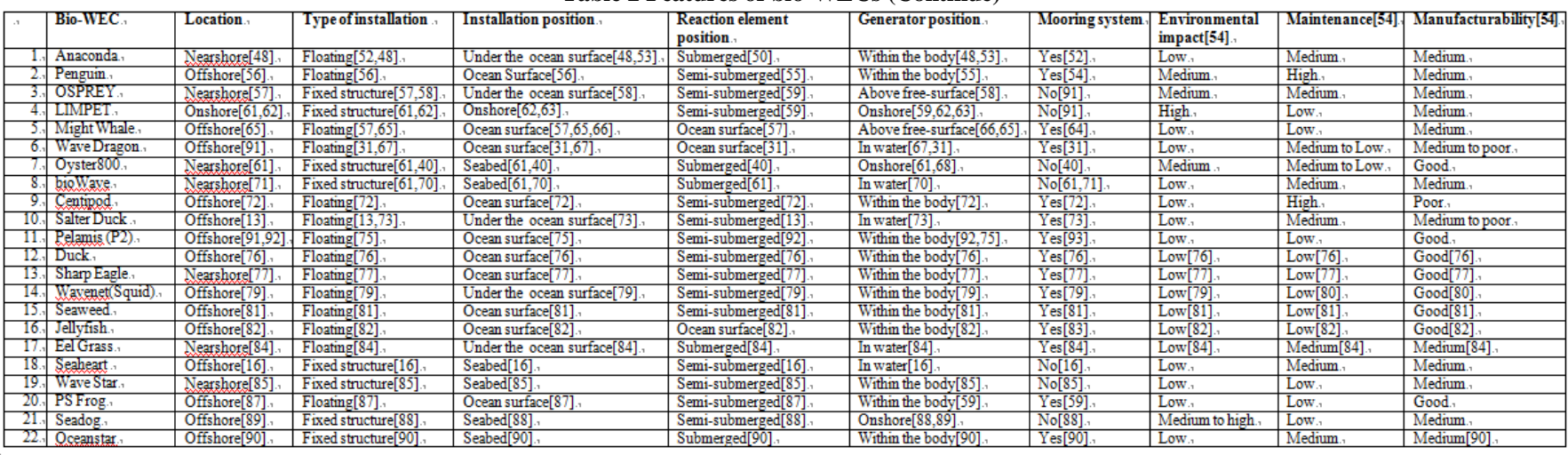

Then the features of the bio-WECs are expressed as the symbol in the Tab.3. The biological features are represented as $\mathrm{A}_{1}$ :Shape, $\mathrm{A}_{2}$ :Principle, $\mathrm{A}_{3}$ :Motion, $\mathrm{A}_{4}$ :Behaviour, $\mathrm{A}_{5}$ :Structure, $\mathrm{A}_{6}:$ Function. $\mathrm{B}_{1}$ :Anaconda, $\mathrm{B}_{2}$ :Penguin, $\mathrm{B}_{3}$ :Osprey, $\mathrm{B}_{4}$ :Limpet, $\mathrm{B}_{5}$ :Whale, $\mathrm{B}_{6}$ :Dragon, $\mathrm{B}_{7}$ :Oyster, $\mathrm{B}_{8}:$ Kelp, $\mathrm{K}_{9}$ :Centipod, $\mathrm{B}_{10}$ :Duck, $\mathrm{B}_{11}$ :Sea snake, $\mathrm{B}_{12}$ :Eagle, $\mathrm{B}_{13}$ :Squid, $\mathrm{B}_{14}$ :Seaweed, $\mathrm{B}_{15}$ :Jellyfish, $\mathrm{B}_{16}$ :Eel grass, $\mathrm{B}_{17}$ :Sea star, $\mathrm{B}_{18}$ :Frog, $\mathrm{B}_{19}$ :Fur seal, $\mathrm{B}_{20}$ :Human heart. $\mathrm{C}_{1}$ :Reptilian, $\mathrm{C}_{2}$ :Human, $\mathrm{C}_{3}$ :Aves, $\mathrm{C}_{4}$ :Gastropoda, $\mathrm{C}_{5}$ :Mammal, $\mathrm{C}_{6}$ :Virture, $\mathrm{C}_{7}$ :Bivalvia, $\quad \mathrm{C}_{8}$ :Phaeosporeae, $\quad \mathrm{C}_{9}$ :Chilopoda, $\mathrm{C}_{10}$ :Cephalopoda, $\quad \mathrm{C}_{11}$ :Polyphyletic, $\quad \mathrm{C}_{12}$ :Cnidaria, $\mathrm{C}_{13}$ :Zosteraceae, $\quad \mathrm{C}_{14}$ :Asteroidea, $\quad \mathrm{C}_{15}$ :Amphibia, $\mathrm{C}_{16}$ : Arctocephalinae, $\mathrm{C}_{17}$ :Asterozoa. The engineering features are represented as $D_{1}$ :Bulge wave, $D_{2}$ :Rotating mass, $\mathrm{D}_{3}$ :Oscillating water column, $\mathrm{D}_{4}$ :Overtopping, D5:Oscillating wave surge converter, $\mathrm{D}_{6}$ :Attenuator, $\mathrm{D}_{7}$ :Point absorber, $\mathrm{E}_{4}$ :Roll, $\mathrm{E}_{5}$ :Yaw, $\mathrm{E}_{6}$ :Pitch, $\mathrm{E}_{7}$ :Oscillating water column, $\mathrm{E}_{8}$ :Overtopping, E9:Bulge wave. $\mathrm{F}_{1}:$ Hydraulic turbine, $\mathrm{F}_{2}$ :Air turbine, $\mathrm{F}_{3}:$ Hydraulic motor, $\mathrm{F}_{4}$ :Linear electrical generator. $\mathrm{G}_{1}:<=500, \quad \mathrm{G}_{2}: 500-1000, \mathrm{G}_{3}: 1000-1500, \mathrm{G}_{4}: 1500-2000$, $\mathrm{G}_{5}: 2000-2500, \mathrm{G}_{6}:>2500, \mathrm{G}_{7}:$ Unknown. $\mathrm{H}_{1}:<=20, \mathrm{H}_{2}: 20-40$, $\mathrm{H}_{3}: 40-60, \mathrm{H}_{4}: 60-80, \mathrm{H}_{5}:$ Unknown. $\mathrm{I}_{1}:<=10, \mathrm{I}_{2}: 10-20, \mathrm{I}_{3}: 20-30$ $\mathrm{I}_{4}: 30-40, \quad \mathrm{I}_{5}: 40-50, \quad \mathrm{I}_{6}:>50, \quad \mathrm{I}_{7}:$ Unknown. $\mathrm{J}_{1}$ :Onshore, $\mathrm{J}_{2}$ :Nearshore, $\mathrm{J}_{3}$ :Offshore. $\mathrm{K}_{1}$ :Floating, $\mathrm{K}_{2}$ :Fixed structure. $\mathrm{L}_{1}$ :Ocean surface, $\mathrm{L}_{2}$ :Under the ocean surface, $\mathrm{L}_{3}$ :Seabed, $\mathrm{L}_{4}$ :Onshore. $\mathrm{M}_{1}:$ Submerged, $\mathrm{M}_{2}:$ Semi-submerged, $\mathrm{M}_{3}$ :Ocean surface. $\mathrm{N}_{1}$ :Within the body, $\mathrm{N}_{2}:$ In water, $\mathrm{N}_{3}$ :Above free surface, $\mathrm{N}_{4}$ :Onshore. $\mathrm{O}_{1}$ :Yes. $\mathrm{O}_{2}$ :No. $\mathrm{P}_{1}$ :High, $\mathrm{P}_{2}$ :Medium, $\mathrm{P}_{3}$ :Low, $\mathrm{P}_{4}$ :Medium to high. $\mathrm{Q}_{1}$ :High, $\mathrm{Q}_{2}$ :Medium, $\mathrm{Q}_{3}$ :Low, $\mathrm{Q}_{4}$ :Medium to low. $\mathrm{R}_{1}$ :Good, $\mathrm{R}_{2}$ :Medium, $\mathrm{R}_{3}$ :Poor, $\mathrm{R}_{4}$ :Medium to poor. The featured itemsets are shown as Tab.4. 


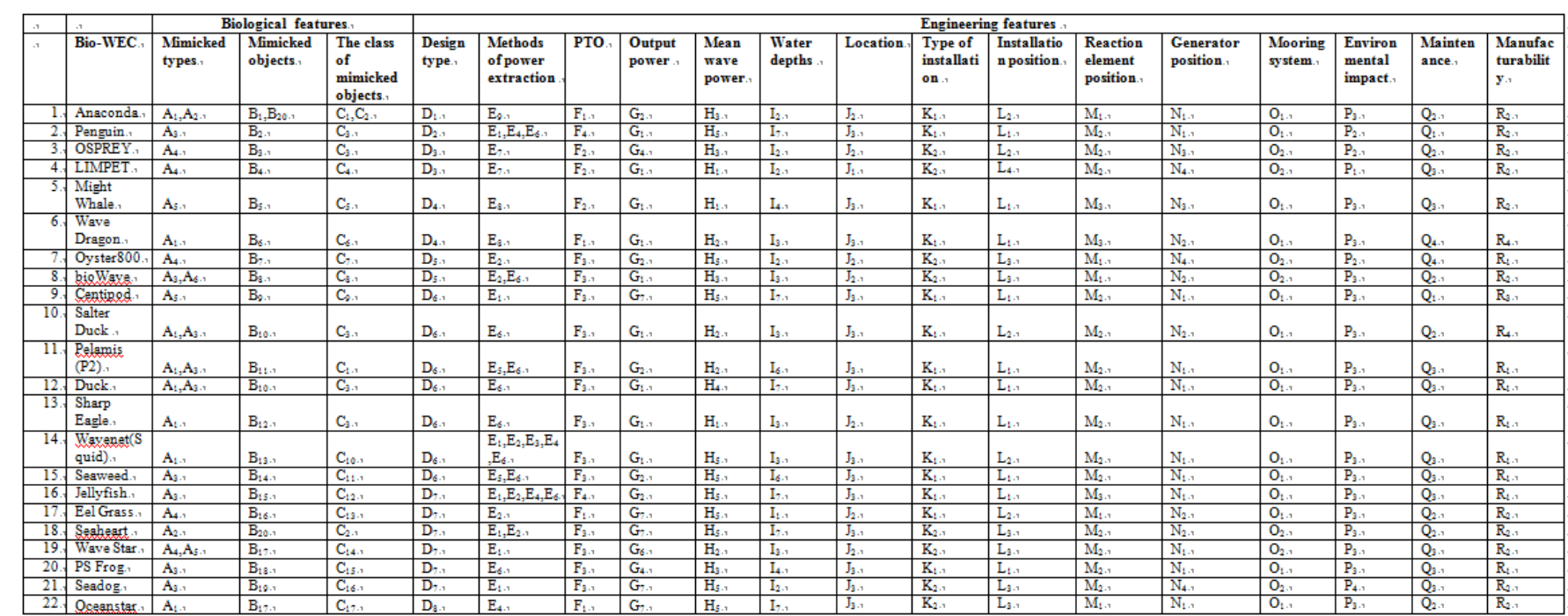

Table 4 Table of featured itemsets

\begin{tabular}{|c|c|}
\hline Index & Biological Features - Engineering Features \\
\hline 1 & $\mathrm{~A}_{1} \mathrm{~A}_{2} \mathrm{~B}_{1} \mathrm{~B}_{20} \mathrm{C}_{1} \mathrm{C}_{2}-\mathrm{D}_{1} \mathrm{E}_{9} \mathrm{~F}_{1} \mathrm{G}_{2} \mathrm{H}_{3} \mathrm{I}_{2} \mathrm{~J}_{2} \mathrm{~K}_{1} \mathrm{~L}_{2} \mathrm{M}_{1} \mathrm{~N}_{1} \mathrm{O}_{1} \mathrm{P}_{3} \mathrm{Q}_{2} \mathrm{R}_{2}$ \\
\hline 2 & $\mathrm{~A}_{3} \mathrm{~B}_{2} \mathrm{C}_{3}-\mathrm{D}_{2} \mathrm{E}_{1} \mathrm{E}_{4} \mathrm{E}_{6} \mathrm{~F}_{4} \mathrm{G}_{1} \mathrm{H}_{5} \mathrm{I}_{7} \mathrm{~J}_{3} \mathrm{~K}_{1} \mathrm{~L}_{1} \mathrm{M}_{2} \mathrm{~N}_{1} \mathrm{O}_{1} \mathrm{P}_{2} \mathrm{Q}_{1} \mathrm{R}_{2}$ \\
\hline 3 & $\mathrm{~A}_{4} \mathrm{~B}_{3} \mathrm{C}_{3}-\mathrm{D}_{3} \mathrm{E}_{7} \mathrm{~F}_{2} \mathrm{G}_{4} \mathrm{H}_{3} \mathrm{I}_{2} \mathrm{~J}_{2} \mathrm{~K}_{2} \mathrm{~L}_{2} \mathrm{M}_{2} \mathrm{~N}_{3} \mathrm{O}_{2} \mathrm{P}_{2} \mathrm{Q}_{2} \mathrm{R}_{2}$ \\
\hline 4 & $\mathrm{~A}_{4} \mathrm{~B}_{4} \mathrm{C}_{4}-\mathrm{D}_{3} \mathrm{E}_{7} \mathrm{~F}_{2} \mathrm{G}_{1} \mathrm{H}_{1} \mathrm{I}_{2} \mathrm{~J}_{1} \mathrm{~K}_{2} \mathrm{~L}_{4} \mathrm{M}_{2} \mathrm{~N}_{4} \mathrm{O}_{2} \mathrm{P}_{1} \mathrm{Q}_{3} \mathrm{R}_{2}$ \\
\hline 5 & $\mathrm{~A}_{5} \mathrm{~B}_{5} \mathrm{C}_{5}-\mathrm{D}_{4} \mathrm{E}_{8} \mathrm{~F}_{2} \mathrm{G}_{1} \mathrm{H}_{1} \mathrm{I}_{4} \mathrm{~J}_{3} \mathrm{~K}_{1} \mathrm{~L}_{1} \mathrm{M}_{3} \mathrm{~N}_{3} \mathrm{O}_{1} \mathrm{P}_{3} \mathrm{Q}_{3} \mathrm{R}_{2}$ \\
\hline 6 & $\mathrm{~A}_{1} \mathrm{~B}_{6} \mathrm{C}_{6}-\mathrm{D}_{4} \mathrm{E}_{8} \mathrm{~F}_{1} \mathrm{G}_{1} \mathrm{H}_{2} \mathrm{I}_{3} \mathrm{~J}_{3} \mathrm{~K}_{1} \mathrm{~L}_{1} \mathrm{M}_{3} \mathrm{~N}_{2} \mathrm{O}_{1} \mathrm{P}_{3} \mathrm{Q}_{4} \mathrm{R}_{4}$ \\
\hline 7 & $\mathrm{~A}_{4} \mathrm{~B}_{7} \mathrm{C}_{7}-\mathrm{D}_{5} \mathrm{E}_{2} \mathrm{~F}_{3} \mathrm{G}_{2} \mathrm{H}_{5} \mathrm{I}_{2} \mathrm{~J}_{2} \mathrm{~K}_{2} \mathrm{~L}_{3} \mathrm{M}_{1} \mathrm{~N}_{4} \mathrm{O}_{2} \mathrm{P}_{2} \mathrm{Q}_{4} \mathrm{R}_{1}$ \\
\hline 8 & $\mathrm{~A}_{3} \mathrm{~A}_{6} \mathrm{~B}_{8} \mathrm{C}_{8}-\mathrm{D}_{5} \mathrm{E}_{2} \mathrm{E}_{6} \mathrm{~F}_{3} \mathrm{G}_{1} \mathrm{H}_{3} \mathrm{I}_{3} \mathrm{~J}_{2} \mathrm{~K}_{2} \mathrm{~L}_{3} \mathrm{M}_{1} \mathrm{~N}_{2} \mathrm{O}_{2} \mathrm{P}_{3} \mathrm{Q}_{2} \mathrm{R}_{2}$ \\
\hline 9 & $\mathrm{~A}_{5} \mathrm{~B}_{9} \mathrm{C}_{9}-\mathrm{D}_{6} \mathrm{E}_{1} \mathrm{~F}_{3} \mathrm{G}_{7} \mathrm{H}_{5} \mathrm{I}_{7} \mathrm{~J}_{3} \mathrm{~K}_{1} \mathrm{~L}_{1} \mathrm{M}_{2} \mathrm{~N}_{1} \mathrm{O}_{1} \mathrm{P}_{3} \mathrm{Q}_{1} \mathrm{R}_{3}$ \\
\hline 10 & $\mathrm{~A}_{1} \mathrm{~A}_{3} \mathrm{~B}_{10} \mathrm{C}_{3}-\mathrm{D}_{6} \mathrm{E}_{6} \mathrm{~F}_{3} \mathrm{G}_{1} \mathrm{H}_{2} \mathrm{I}_{3} \mathrm{~J}_{3} \mathrm{~K}_{1} \mathrm{~L}_{2} \mathrm{M}_{2} \mathrm{~N}_{2} \mathrm{O}_{1} \mathrm{P}_{3} \mathrm{Q}_{2} \mathrm{R}_{4}$ \\
\hline 11 & $\mathrm{~A}_{1} \mathrm{~A}_{3} \mathrm{~B}_{11} \mathrm{C}_{1}-\mathrm{D}_{6} \mathrm{E}_{5} \mathrm{E}_{6} \mathrm{~F}_{3} \mathrm{G}_{2} \mathrm{H}_{2} \mathrm{I}_{6} \mathrm{~J}_{3} \mathrm{~K}_{1} \mathrm{~L}_{1} \mathrm{M}_{2} \mathrm{~N}_{1} \mathrm{O}_{1} \mathrm{P}_{3} \mathrm{Q}_{3} \mathrm{R}_{1}$ \\
\hline 12 & $\mathrm{~A}_{1} \mathrm{~A}_{3} \mathrm{~B}_{10} \mathrm{C}_{3}-\mathrm{D}_{6} \mathrm{E}_{6} \mathrm{~F}_{3} \mathrm{G}_{1} \mathrm{H}_{4} \mathrm{I}_{7} \mathrm{~J}_{3} \mathrm{~K}_{1} \mathrm{~L}_{1} \mathrm{M}_{2} \mathrm{~N}_{1} \mathrm{O}_{1} \mathrm{P}_{3} \mathrm{Q}_{3} \mathrm{R}_{1}$ \\
\hline 13 & $\mathrm{~A}_{1} \mathrm{~B}_{12} \mathrm{C}_{3}-\mathrm{D}_{6} \mathrm{E}_{6} \mathrm{~F}_{3} \mathrm{G}_{1} \mathrm{H}_{1} \mathrm{I}_{3} \mathrm{~J}_{2} \mathrm{~K}_{1} \mathrm{~L}_{1} \mathrm{M}_{2} \mathrm{~N}_{1} \mathrm{O}_{1} \mathrm{P}_{3} \mathrm{Q}_{3} \mathrm{R}_{1}$ \\
\hline 14 & $\mathrm{~A}_{1} \mathrm{~B}_{13} \mathrm{C}_{10}-\mathrm{D}_{6} \mathrm{E}_{1} \mathrm{E}_{2} \mathrm{E}_{3} \mathrm{E}_{4} \mathrm{E}_{6} \mathrm{~F}_{3} \mathrm{G}_{1} \mathrm{H}_{5} \mathrm{I}_{3} \mathrm{~J}_{3} \mathrm{~K}_{1} \mathrm{~L}_{2} \mathrm{M}_{2} \mathrm{~N}_{1} \mathrm{O}_{1} \mathrm{P}_{3} \mathrm{Q}_{3} \mathrm{R}_{1}$ \\
\hline 15 & $\mathrm{~A}_{3} \mathrm{~B}_{14} \mathrm{C}_{11}-\mathrm{D}_{6} \mathrm{E}_{5} \mathrm{E}_{6} \mathrm{~F}_{3} \mathrm{G}_{2} \mathrm{H}_{5} \mathrm{I}_{6} \mathrm{~J}_{3} \mathrm{~K}_{1} \mathrm{~L}_{1} \mathrm{M}_{2} \mathrm{~N}_{1} \mathrm{O}_{1} \mathrm{P}_{3} \mathrm{Q}_{3} \mathrm{R}_{1}$ \\
\hline 16 & $\mathrm{~A}_{3} \mathrm{~B}_{15} \mathrm{C}_{12}-\mathrm{D}_{7} \mathrm{E}_{1} \mathrm{E}_{2} \mathrm{E}_{4} \mathrm{E}_{6} \mathrm{~F}_{4} \mathrm{G}_{2} \mathrm{H}_{5} \mathrm{I}_{7} \mathrm{~J}_{3} \mathrm{~K}_{1} \mathrm{~L}_{1} \mathrm{M}_{3} \mathrm{~N}_{1} \mathrm{O}_{1} \mathrm{P}_{3} \mathrm{Q}_{3} \mathrm{R}_{1}$ \\
\hline 17 & $\mathrm{~A}_{4} \mathrm{~B}_{16} \mathrm{C}_{13}-\mathrm{D}_{7} \mathrm{E}_{2} \mathrm{~F}_{1} \mathrm{G}_{7} \mathrm{H}_{5} \mathrm{I}_{1} \mathrm{~J}_{2} \mathrm{~K}_{1} \mathrm{~L}_{2} \mathrm{M}_{1} \mathrm{~N}_{2} \mathrm{O}_{1} \mathrm{P}_{3} \mathrm{Q}_{2} \mathrm{R}_{2}$ \\
\hline 18 & $\mathrm{~A}_{2} \mathrm{~B}_{20} \mathrm{C}_{2}-\mathrm{D}_{7} \mathrm{E}_{1} \mathrm{E}_{2} \mathrm{~F}_{3} \mathrm{G}_{7} \mathrm{H}_{5} \mathrm{I}_{7} \mathrm{~J}_{3} \mathrm{~K}_{2} \mathrm{~L}_{3} \mathrm{M}_{2} \mathrm{~N}_{2} \mathrm{O}_{2} \mathrm{P}_{3} \mathrm{Q}_{2} \mathrm{R}_{2}$ \\
\hline 19 & $\mathrm{~A}_{4} \mathrm{~A}_{5} \mathrm{~B}_{17} \mathrm{C}_{14}-\mathrm{D}_{7} \mathrm{E}_{1} \mathrm{~F}_{3} \mathrm{G}_{6} \mathrm{H}_{2} \mathrm{I}_{3} \mathrm{~J}_{2} \mathrm{~K}_{2} \mathrm{~L}_{3} \mathrm{M}_{2} \mathrm{~N}_{1} \mathrm{O}_{2} \mathrm{P}_{3} \mathrm{Q}_{3} \mathrm{R}_{2}$ \\
\hline 20 & $\mathrm{~A}_{3} \mathrm{~B}_{18} \mathrm{C}_{15}-\mathrm{D}_{7} \mathrm{E}_{6} \mathrm{~F}_{3} \mathrm{G}_{4} \mathrm{H}_{3} \mathrm{~L}_{4} \mathrm{~J}_{3} \mathrm{~K}_{1} \mathrm{~L}_{1} \mathrm{M}_{2} \mathrm{~N}_{1} \mathrm{O}_{1} \mathrm{P}_{3} \mathrm{Q}_{3} \mathrm{R}_{1}$ \\
\hline 21 & $\mathrm{~A}_{3} \mathrm{~B}_{19} \mathrm{C}_{16}-\mathrm{D}_{7} \mathrm{E}_{1} \mathrm{~F}_{3} \mathrm{G}_{7} \mathrm{H}_{5} \mathrm{I}_{2} \mathrm{~J}_{3} \mathrm{~K}_{2} \mathrm{~L}_{3} \mathrm{M}_{2} \mathrm{~N}_{4} \mathrm{O}_{2} \mathrm{P}_{4} \mathrm{Q}_{3} \mathrm{R}_{2}$ \\
\hline 22 & $\mathrm{~A}_{1} \mathrm{~B}_{17} \mathrm{C}_{17}-\mathrm{D}_{8} \mathrm{E}_{4} \mathrm{~F}_{1} \mathrm{G}_{7} \mathrm{H}_{5} \mathrm{I}_{7} \mathrm{~J}_{3} \mathrm{~K}_{2} \mathrm{~L}_{3} \mathrm{M}_{1} \mathrm{~N}_{1} \mathrm{O}_{1} \mathrm{P}_{3} \mathrm{Q}_{2} \mathrm{R}_{2}$ \\
\hline
\end{tabular}

\subsection{Acquiring frequent itemsets}

Apriori algorithm is particularly the kind of bottom-up algorithm that needs to combine small frequent itemsets and generates numerous candidate itemsets. It sets the minimum support MinSupport=3, and starts from frequent 2-set to max frequent 15 -set, until more frequent 15 -set can't be found. Frequent itemsets obtained from the biological featuresengineering features sets are shown as follows.

$\mathrm{L}_{2}=\left\{\mathrm{A}_{1} \mathrm{Q}_{2}, \mathrm{~A}_{3} \mathrm{C}_{3}, \mathrm{~A}_{3} \mathrm{R}_{2}, \mathrm{~A}_{5} \mathrm{P}_{3}\right\}$,

$\mathrm{L}_{4}=\left\{\mathrm{A}_{1} \mathrm{~F}_{1} \mathrm{O}_{1} \mathrm{P}_{3}, \mathrm{~A}_{3} \mathrm{E}_{1} \mathrm{H}_{5} \mathrm{~J}_{3}, \mathrm{~A}_{3} \mathrm{D}_{7} \mathrm{~J}_{3} \mathrm{Q}_{3}, \mathrm{~A}_{4} \mathrm{M}_{2} \mathrm{O}_{2} \mathrm{R}_{2}, \mathrm{~A}_{4} \mathrm{I}_{2} \mathrm{~K}_{2} \mathrm{O}_{2}\right\}$,

$\mathrm{L}_{5}=\left\{\mathrm{A}_{1} \mathrm{~K}_{1} \mathrm{~L}_{2} \mathrm{O}_{1} \mathrm{P}_{3}, \mathrm{~A}_{4} \mathrm{~J}_{2} \mathrm{~K}_{2} \mathrm{O}_{2} \mathrm{R}_{2}, \mathrm{~A}_{3} \mathrm{E}_{6} \mathrm{~F}_{3} \mathrm{G}_{1} \mathrm{P}_{3}\right\}$,

$\mathrm{L}_{6}=\left\{\mathrm{A}_{1} \mathrm{H}_{2} \mathrm{~J}_{3} \mathrm{~K}_{1} \mathrm{O}_{1} \mathrm{P}_{3}\right\}$

$\mathrm{L}_{7}=\left\{\mathrm{A}_{3} \mathrm{H}_{5} \mathrm{~J}_{3} \mathrm{~K}_{1} \mathrm{~L}_{1} \mathrm{~N}_{1} \mathrm{O}_{1}, \mathrm{~A}_{3} \mathrm{I}_{7} \mathrm{~J}_{3} \mathrm{~K}_{1} \mathrm{~L}_{1} \mathrm{~N}_{1} \mathrm{O}_{1}\right\}$,

$\mathrm{L}_{10}=\left\{\mathrm{A}_{1} \mathrm{C}_{3} \mathrm{D}_{6} \mathrm{E}_{6} \mathrm{~F}_{3} \mathrm{G}_{1} \mathrm{~K}_{1} \mathrm{M}_{2} \mathrm{O}_{1} \mathrm{P}_{3}, \mathrm{~A}_{1} \mathrm{~A}_{3} \mathrm{D}_{6} \mathrm{E}_{6} \mathrm{~F}_{3} \mathrm{~J}_{3} \mathrm{~K}_{1} \mathrm{M}_{2} \mathrm{O}_{1} \mathrm{P}_{3}\right.$, $\left.\mathrm{A}_{1} \mathrm{D}_{6} \mathrm{E}_{6} \mathrm{~F}_{3} \mathrm{G}_{1} \mathrm{I}_{3} \mathrm{~J}_{3} \mathrm{~K}_{1} \mathrm{~L}_{1} \mathrm{M}_{2}, \mathrm{~A}_{3} \mathrm{G}_{2} \mathrm{~J}_{3} \mathrm{~K}_{1} \mathrm{~L}_{1} \mathrm{~N}_{1} \mathrm{O}_{1} \mathrm{P}_{3} \mathrm{Q}_{3} \mathrm{R}_{1}\right\}$, $\mathrm{L}_{13}=\left\{\mathrm{A}_{3} \mathrm{D}_{6} \mathrm{E}_{6} \mathrm{~F}_{3} \mathrm{~J}_{3} \mathrm{~K}_{1} \mathrm{~L}_{1} \mathrm{M}_{2} \mathrm{~N}_{1} \mathrm{O}_{1} \mathrm{P}_{3} \mathrm{Q}_{3} \mathrm{R}_{1}\right\}$.

Then the frequent itemset $\left\{\mathrm{A}_{3} \mathrm{C}_{3}\right\}$ that is not associated with engineering features is removed.

\subsection{Generating association rules}

$$
\text { If } \frac{\text { Support _ count }(L)}{\text { Support_count }(c)} \geq \text { conf }_{\min } \text {, then the association rule is }
$$

" $c \Rightarrow(L-c)$ "according to the minimum confidence threshold Conf $_{\text {min }}$, the number of records Support_count $(L)$ containing frequent itemsets $L$, and the number of records Support_count $(c)$ containing set $c$. Relationships between biological features and engineering features can be analyzed. Their relevancies can be evaluated by calculating the confidence in Tab.5. The rules obtained are shown on Tab.6.

Table 5 Rules reasoning

\begin{tabular}{|c|c|c|}
\hline & \multicolumn{2}{|c|}{ Biological features-engineering features } \\
\hline & Association rules & Confidence \\
\hline 1 & $\mathrm{Q}_{2} \rightarrow \mathrm{A}_{1}$ & $\mathrm{~A}_{1} \mathrm{Q}_{2} / \mathrm{Q}_{2}=3 / 7$ \\
\hline 2 & $\mathrm{R}_{2} \rightarrow \mathrm{A}_{3}$ & $\mathrm{~A}_{3} \mathrm{R}_{2} / \mathrm{R}_{2}=3 / 11$ \\
\hline 3 & $\mathrm{P}_{3} \rightarrow \mathrm{A}_{5}$ & $\mathrm{~A}_{5} \mathrm{P}_{3} / \mathrm{P}_{3}=3 / 17$ \\
\hline 4 & $\mathrm{~F}_{1} \mathrm{O}_{1} \mathrm{P}_{3} \rightarrow \mathrm{A}_{1}$ & $\mathrm{~A}_{1} \mathrm{~F}_{1} \mathrm{O}_{1} \mathrm{P}_{3} / \mathrm{F}_{1} \mathrm{O}_{1} \mathrm{P}_{3}=3 / 4$ \\
\hline 5 & $\mathrm{E}_{1} \mathrm{H}_{5} \mathrm{~J}_{3} \rightarrow \mathrm{A}_{3}$ & $\mathrm{~A}_{3} \mathrm{E}_{1} \mathrm{H}_{5} \mathrm{~J}_{3} / \mathrm{E}_{1} \mathrm{H}_{5} \mathrm{~J}_{3}=3 / 6$ \\
\hline 6 & $\mathrm{D}_{7} \mathrm{~J}_{3} \mathrm{Q}_{3} \rightarrow \mathrm{A}_{3}$ & $\mathrm{~A}_{3} \mathrm{D}_{7} \mathrm{~J}_{3} \mathrm{Q}_{3} / \mathrm{D}_{7} \mathrm{~J}_{3} \mathrm{Q}_{3}=3 / 3$ \\
\hline 7 & $\mathrm{M}_{2} \mathrm{O}_{2} \mathrm{R}_{2} \rightarrow \mathrm{A}_{4}$ & $\mathrm{~A}_{4} \mathrm{M}_{2} \mathrm{O}_{2} \mathrm{R}_{2} / \mathrm{M}_{2} \mathrm{O}_{2} \mathrm{R}_{2}=3 / 5$ \\
\hline 8 & $\mathrm{I}_{2} \mathrm{~K}_{2} \mathrm{O}_{2} \rightarrow \mathrm{A}_{4}$ & $\mathrm{~A}_{4} \mathrm{I}_{2} \mathrm{~K}_{2} \mathrm{O}_{2} / \mathrm{I}_{2} \mathrm{~K}_{2} \mathrm{O}_{2}=3 / 4$ \\
\hline 9 & $\mathrm{~K}_{1} \mathrm{~L}_{2} \mathrm{O}_{1} \mathrm{P}_{3} \rightarrow \mathrm{A}_{1}$ & $\mathrm{~A}_{1} \mathrm{~K}_{1} \mathrm{~L}_{2} \mathrm{O}_{1} \mathrm{P}_{3} / \mathrm{K}_{1} \mathrm{~L}_{2} \mathrm{O}_{1} \mathrm{P}_{3}=3 / 4$ \\
\hline 10 & $\mathrm{~J}_{2} \mathrm{~K}_{2} \mathrm{O}_{2} \mathrm{R}_{2} \rightarrow \mathrm{A}_{4}$ & $\mathrm{~A}_{4} \mathrm{~J}_{2} \mathrm{~K}_{2} \mathrm{O}_{2} / \mathrm{J}_{2} \mathrm{~K}_{2} \mathrm{O}_{2}=3 / 4$ \\
\hline 11 & $\mathrm{E}_{6} \mathrm{~F}_{3} \mathrm{G}_{1} \mathrm{P}_{3} \rightarrow \mathrm{A}_{3}$ & $\mathrm{~A}_{3} \mathrm{E}_{6} \mathrm{~F}_{3} \mathrm{G}_{1} \mathrm{P}_{3} / \mathrm{E}_{6} \mathrm{~F}_{3} \mathrm{G}_{1} \mathrm{P}_{3}=3 / 5$ \\
\hline 12 & $\mathrm{H}_{2} \mathrm{~J}_{3} \mathrm{~K}_{1} \mathrm{O}_{1} \mathrm{P}_{3} \rightarrow \mathrm{A}_{1}$ & $\mathrm{~A}_{1} \mathrm{H}_{2} \mathrm{~J}_{3} \mathrm{~K}_{1} \mathrm{O}_{1} \mathrm{P}_{3} / \mathrm{H}_{2} \mathrm{~J}_{3} \mathrm{~K}_{1} \mathrm{O}_{1} \mathrm{P}_{3}=3 / 3$ \\
\hline 13 & $\mathrm{H}_{5} \mathrm{~J}_{3} \mathrm{~K}_{1} \mathrm{~L}_{1} \mathrm{~N}_{1} \mathrm{O}_{1} \rightarrow \mathrm{A}_{3}$ & $\begin{array}{l}\mathrm{A}_{3} \mathrm{H}_{5} \mathrm{~J}_{3} \mathrm{~K}_{1} \mathrm{~L}_{1} \mathrm{~N}_{1} \mathrm{O}_{1} / \\
\mathrm{H}_{5} \mathrm{~J}_{3} \mathrm{~K}_{1} \mathrm{~L}_{1} \mathrm{~N}_{1} \mathrm{O}_{1}=3 / 4\end{array}$ \\
\hline 14 & $\mathrm{I}_{7} \mathrm{~J}_{3} \mathrm{~K}_{1} \mathrm{~L}_{1} \mathrm{~N}_{1} \mathrm{O}_{1} \rightarrow \mathrm{A}_{3}$ & $\mathrm{~A}_{3} \mathrm{I}_{7} \mathrm{~J}_{3} \mathrm{~K}_{1} \mathrm{~L}_{1} \mathrm{~N}_{1} \mathrm{O}_{1} / \mathrm{I}_{7} \mathrm{~J}_{3} \mathrm{~K}_{1} \mathrm{~L}_{1} \mathrm{~N}_{1} \mathrm{O}_{1}=3 / 4$ \\
\hline 15 & $\mathrm{D}_{6} \mathrm{E}_{6} \mathrm{~F}_{3} \mathrm{G}_{1} \mathrm{~K}_{1} \mathrm{M}_{2} \mathrm{O}_{1} \mathrm{P}_{3} \rightarrow \mathrm{A}_{1} \mathrm{C}_{3}$ & $\begin{array}{l}\mathrm{A}_{1} \mathrm{C}_{3} \mathrm{D}_{6} \mathrm{E}_{6} \mathrm{~F}_{3} \mathrm{G}_{1} \mathrm{~K}_{1} \mathrm{M}_{2} \mathrm{O}_{1} \mathrm{P}_{3} / \\
\mathrm{D}_{6} \mathrm{E}_{6} \mathrm{~F}_{3} \mathrm{G}_{1} \mathrm{~K}_{1} \mathrm{M}_{2} \mathrm{O}_{1} \mathrm{P}_{3}=3 / 4 \\
\end{array}$ \\
\hline 16 & $\mathrm{D}_{6} \mathrm{E}_{6} \mathrm{~F}_{3} \mathrm{~J}_{3} \mathrm{~K}_{1} \mathrm{M}_{2} \mathrm{O}_{1} \mathrm{P}_{3} \rightarrow \mathrm{A}_{1} \mathrm{~A}_{3}$ & $\begin{array}{l}\mathrm{A}_{1} \mathrm{~A}_{3} \mathrm{D}_{6} \mathrm{E}_{6} \mathrm{~F}_{3} \mathrm{~J}_{3} \mathrm{~K}_{1} \mathrm{M}_{2} \mathrm{O}_{1} \mathrm{P}_{3} / \\
\mathrm{D}_{6} \mathrm{E}_{6} \mathrm{~F}_{3} \mathrm{~J}_{3} \mathrm{~K}_{1} \mathrm{M}_{2} \mathrm{O}_{1} \mathrm{P}_{3}=3 / 5\end{array}$ \\
\hline 17 & $\mathrm{D}_{6} \mathrm{E}_{6} \mathrm{~F}_{3} \mathrm{G}_{1} \mathrm{I}_{3} \mathrm{~J}_{3} \mathrm{~K}_{1} \mathrm{~L}_{1} \mathrm{M}_{2} \rightarrow \mathrm{A}_{1}$ & $\begin{array}{l}\mathrm{A}_{1} \mathrm{D}_{6} \mathrm{E}_{6} \mathrm{~F}_{3} \mathrm{G}_{1} \mathrm{I}_{3} \mathrm{~J}_{3} \mathrm{~K}_{1} \mathrm{~L}_{1} \mathrm{M}_{2} / \\
\mathrm{D}_{6} \mathrm{E}_{6} \mathrm{~F}_{3} \mathrm{G}_{1} \mathrm{I}_{3} \mathrm{~J}_{3} \mathrm{~K}_{1} \mathrm{~L}_{1} \mathrm{M}_{2}=3 / 3\end{array}$ \\
\hline 18 & $\mathrm{G}_{2} \mathrm{~J}_{3} \mathrm{~K}_{1} \mathrm{~L}_{1} \mathrm{~N}_{1} \mathrm{O}_{1} \mathrm{P}_{3} \mathrm{Q}_{3} \mathrm{R}_{1} \rightarrow \mathrm{A}_{3}$ & $\begin{array}{l}\mathrm{A}_{3} \mathrm{G}_{2} \mathrm{~J}_{3} \mathrm{~K}_{1} \mathrm{~L}_{1} \mathrm{~N}_{1} \mathrm{O}_{1} \mathrm{P}_{3} \mathrm{Q}_{3} \mathrm{R}_{1} / \\
\mathrm{G}_{2} \mathrm{~J}_{3} \mathrm{~K}_{1} \mathrm{~L}_{1} \mathrm{~N}_{1} \mathrm{O}_{1} \mathrm{P}_{3} \mathrm{Q}_{3} \mathrm{R}_{1}=3 / 3\end{array}$ \\
\hline 19 & $\begin{array}{l}\mathrm{D}_{6} \mathrm{E}_{6} \mathrm{~F}_{3} \mathrm{~J}_{3} \mathrm{~K}_{1} \mathrm{~L}_{1} \mathrm{M}_{2} \mathrm{~N}_{1} \mathrm{O}_{1} \mathrm{P}_{3} \mathrm{Q}_{3} \\
\mathrm{R}_{1} \rightarrow \mathrm{A}_{3}\end{array}$ & $\begin{array}{l}\mathrm{A}_{3} \mathrm{D}_{6} \mathrm{E}_{6} \mathrm{~F}_{3} \mathrm{~J}_{3} \mathrm{~K}_{1} \mathrm{~L}_{1} \mathrm{M}_{2} \mathrm{~N}_{1} \mathrm{O}_{1} \mathrm{P}_{3} \mathrm{Q}_{3} \mathrm{R}_{1} / \\
\mathrm{D}_{6} \mathrm{E}_{6} \mathrm{~F}_{3} \mathrm{~J}_{3} \mathrm{~K}_{1} \mathrm{~L}_{1} \mathrm{M}_{2} \mathrm{~N}_{1} \mathrm{O}_{1} \mathrm{P}_{3} \mathrm{Q}_{3} \mathrm{R}_{1}=3 / 3\end{array}$ \\
\hline
\end{tabular}

\begin{tabular}{|l|l|l|}
\multicolumn{2}{|c|}{ Table 6 Extracted rules } \\
\begin{tabular}{|c|l|l|}
\hline \multicolumn{1}{|c|}{} & $\begin{array}{l}\text { Biological features- } \\
\text { engineering } \\
\text { features (Conf } \\
\text { =0.7) }\end{array}$ & \multicolumn{1}{c|}{ Explanation of rules } \\
\hline 1 & $\begin{array}{l}\text { Rule } 4: \\
\mathrm{F}_{1} \mathrm{O}_{1} \mathrm{P}_{3} \rightarrow \mathrm{A}_{1}, \\
\text { conf }=3 / 4=0.75\end{array}$ & $\begin{array}{l}\text { The confidence of using: mimicking the } \\
\text { shape to design a WEC with hydraulic } \\
\text { turbine, the mooring system and low }\end{array}$ \\
\hline
\end{tabular}
\end{tabular}




\begin{tabular}{|c|c|c|}
\hline & & environmental impact is 0.75 . \\
\hline 2 & $\begin{array}{l}\text { Rule 6: } \\
\mathrm{D}_{7} \mathrm{~J}_{3} \mathrm{Q}_{3} \rightarrow \mathrm{A}_{3} \\
\text { conf }=3 / 3=1\end{array}$ & $\begin{array}{l}\text { The confidence of using: mimicking the } \\
\text { motion to design an offshore point } \\
\text { absorber WEC with low maintenance is } 1 .\end{array}$ \\
\hline 3 & $\begin{array}{l}\text { Rule 8: } \\
\mathrm{I}_{2} \mathrm{~K}_{2} \mathrm{O}_{2} \rightarrow \mathrm{A}_{4} \\
\text { conf }=3 / 4=0.75\end{array}$ & $\begin{array}{l}\text { The confidence of using: mimicking the } \\
\text { behaviour to design a WEC with } 10-20 \mathrm{~m} \\
\text { water depth, fixed structure and without } \\
\text { the mooring system is } 0.75 \text {. }\end{array}$ \\
\hline 4 & $\begin{array}{l}\text { Rule 9: } \\
\mathrm{K}_{1} \mathrm{~L}_{2} \mathrm{O}_{1} \mathrm{P}_{3} \rightarrow \mathrm{A}_{1} \\
\text { conf }=3 / 4=0.75\end{array}$ & $\begin{array}{l}\text { The confidence of using: mimicking the } \\
\text { shape to design a floating under the ocean } \\
\text { surface WEC with the mooring system and } \\
\text { low environmental impact is } 0.75 \text {. }\end{array}$ \\
\hline 5 & $\begin{array}{l}\text { Rule } 10: \\
\mathrm{J}_{2} \mathrm{~K}_{2} \mathrm{O}_{2} \mathrm{R}_{2} \rightarrow \mathrm{A}_{4} \\
\text { conf }=3 / 4=0.75\end{array}$ & $\begin{array}{l}\text { The confidence of using: mimicking the } \\
\text { behaviour to design a nearshore WEC with } \\
\text { fixed structure, medium manufacturability } \\
\text { and without the mooring system is } 0.75 \text {. }\end{array}$ \\
\hline 6 & $\begin{array}{l}\text { Rule 12: } \\
\mathrm{H}_{2} \mathrm{~J}_{3} \mathrm{~K}_{1} \mathrm{O}_{1} \mathrm{P}_{3} \rightarrow \mathrm{A}_{1} \\
\text { conf }=3 / 3=1\end{array}$ & $\begin{array}{l}\text { The confidence of using: mimicking the } \\
\text { shape to design an offshore floating WEC } \\
\text { with } 20-40 \mathrm{KW} / \mathrm{m} \text { mean wave power, the } \\
\text { mooring system and low environmental } \\
\text { impact is } 1 \text {. }\end{array}$ \\
\hline 7 & $\begin{array}{l}\text { Rule 13: } \\
\mathrm{H}_{5} \mathrm{~J}_{3} \mathrm{~K}_{1} \mathrm{~L}_{1} \mathrm{~N}_{1} \mathrm{O}_{1} \rightarrow \mathrm{A}_{3} \\
\text { conf }=3 / 4=0.75\end{array}$ & $\begin{array}{l}\text { The confidence of using: mimicking the } \\
\text { motion to design an offshore floating at } \\
\text { ocean surface WEC with the generator } \\
\text { positioned within the body, the mooring } \\
\text { system and unknown mean wave power is } \\
0.75 \text {. }\end{array}$ \\
\hline 8 & $\begin{array}{l}\text { Rule 14: } \\
\mathrm{I}_{7} \mathrm{~J}_{3} \mathrm{~K}_{1} \mathrm{~L}_{1} \mathrm{~N}_{1} \mathrm{O}_{1} \rightarrow \mathrm{A}_{3} \\
\operatorname{conf}=3 / 4=0.75\end{array}$ & $\begin{array}{l}\text { The confidence of using: mimicking the } \\
\text { motion to design an offshore floating at } \\
\text { ocean surface WEC with the generator } \\
\text { positioned within the body, the mooring } \\
\text { system and unknown water depth is } 0.75 \text {. }\end{array}$ \\
\hline 9 & $\begin{array}{l}\text { Rule } 15: \\
\mathrm{D}_{6} \mathrm{E}_{6} \mathrm{~F}_{3} \mathrm{G}_{1} \mathrm{~K}_{1} \mathrm{M}_{2} \mathrm{O}_{1} \mathrm{P}_{3} \\
\rightarrow \mathrm{A}_{1} \mathrm{C}_{3} \\
\text { conf }=3 / 4=0.75\end{array}$ & $\begin{array}{l}\text { The confidence of using: mimicking the } \\
\text { shape of Aves to design a floating semi- } \\
\text { submerged attenuator pitch WEC with } \\
\text { hydraulic motor, no more than } 500 \mathrm{kw} \\
\text { output power, the mooring system and low } \\
\text { environmental impact is } 0.75 \text {. }\end{array}$ \\
\hline 10 & $\begin{array}{l}\text { Rule 17: } \\
\mathrm{D}_{6} \mathrm{E}_{6} \mathrm{~F}_{3} \mathrm{G}_{1} \mathrm{I}_{3} \mathrm{~J}_{3} \mathrm{~K}_{1} \mathrm{~L}_{1} \mathrm{M}_{2} \\
\rightarrow \mathrm{A}_{1} \\
\text { conf }=3 / 3=1\end{array}$ & $\begin{array}{l}\text { The confidence of using: mimicking the } \\
\text { shape to design an offshore floating at } \\
\text { ocean surface semi-submerged attenuator } \\
\text { pitch WEC with hydraulic motor, no more } \\
\text { than } 500 \mathrm{kw} \text { output power and working in } \\
20-30 \mathrm{~m} \text { water depths is } 1 \text {. }\end{array}$ \\
\hline 11 & $\begin{array}{l}\text { Rule 18: } \\
\mathrm{G}_{2} \mathrm{~J}_{3} \mathrm{~K}_{1} \mathrm{~L}_{1} \mathrm{~N}_{1} \mathrm{O}_{1} \mathrm{P}_{3} \mathrm{Q}_{3} \mathrm{R} \\
1 \rightarrow \mathrm{A}_{3} \\
\text { conf }=3 / 3=1\end{array}$ & $\begin{array}{l}\text { The confidence of using: mimicking the } \\
\text { motion to design an offshore floating at } \\
\text { ocean surface WEC with the generator } \\
\text { positioned within the body, } 500-1000 \mathrm{kw} \\
\text { output power, the mooring system, low } \\
\text { environmental impact, low maintenance } \\
\text { and good manufacturability is } 1 \text {. }\end{array}$ \\
\hline 12 & $\begin{array}{l}\text { Rule 19: } \\
\mathrm{D}_{6} \mathrm{E}_{6} \mathrm{~F}_{3} \mathrm{~J}_{3} \mathrm{~K}_{1} \mathrm{~L}_{1} \mathrm{M}_{2} \mathrm{~N}_{1} \\
\mathrm{O}_{1} \mathrm{P}_{3} \mathrm{Q}_{3} \mathrm{R}_{1} \rightarrow \mathrm{A}_{3} \\
\text { conf }=3 / 3=1\end{array}$ & $\begin{array}{l}\text { The confidence of using: mimicking the } \\
\text { motion to design an offshore floating at } \\
\text { ocean surface semi-submerged attenuator } \\
\text { pitch WEC with hydraulic motor, the } \\
\text { generator positioned within the body, the } \\
\text { mooring system, low environmental } \\
\text { impact, low maintenance and good } \\
\text { manufacturability is } 1 \text {. }\end{array}$ \\
\hline
\end{tabular}

In order to improve the precision of the rules, new bioWEC information can be added to the symbol table. The new association rules can be mined after updating the set table. Then the new knowledge can be acquired.

\section{Conclusions}

We can not only discover the interesting relations between biological features and engineering features, but also obtain new research trends from the extracted rules. First the offshore floating WECs with the mooring system and low environmental impact are becoming the highlight of research. Next, the development of semi-submerged attenuator pitch
WEC with hydraulic motor and low maintenance will become the research focus. At the same time, the small probability events in the features table of bio-WECs should be noticed because they may become the next research hotspot.

It is currently difficult for designers to develop the 'ideal' biomimetic WEC. But with the assistance of mined data on the rules hidden in the biomimetic WECs, we could effectively use these rules to solve the problems that exist in the current WEC designs and to establish the next generation of WECs with more novel future solutions by imitating the different characteristics of the biomimetic entities.

\section{References}

[1] Portilla J, Sosa J \& Cavaleri L. Wave energy resources: Wave climate and exploitation. Renewable Energy 2013;57: 594-605.

[2] Frid C, Andonegi E, Depestele J, Judd A, Rihan D, Rogers SI \& Kenchington E. The environmental interactions of tidal and wave energy generation devices. Environmental Impact Assessment Review 2012; 32: 133-139.

[3] Scruggs J \& Jacob P. Harvesting Ocean Wave Energy. Science 2009; 323: 1176-1178.

[4] Astariz S \& Iglesias G. The economics of wave energy: A review. Renewable and Sustainable Energy Reviews 2015; 45: 397-408.

[5] Shu LH, Ueda K, Chiu I \& Cheong H. Biologically inspired design. CIRP Annals - Manufacturing Technology 2011; 60: 673-693.

[6] Benyus J. Biomimicry: innovation inspired by nature. New York: William Morrow; 1997.

[7] Mak T \& Shu L. Using descriptions of biological phenomena for idea generation. Research in Engineering Design 2008; 19: 21-28.

[8] Zhang Dh, Li W \& Lin YG. Wave energy in China: Current status and perspectives. Renewable Energy 2009; 34: 2089-2092.

[9] Salter SH, Taylor JR. \& Caldwell NJ. Power conversion mechanisms for wave energy. Proc. Inst. Mech. Eng. Part M J Eng. Maritime Environ 2002; 216: 1-27

[10] EMEC. Wave Developers [online]. Available: 《http://www.emec.org.uk/marine-energy/wave-developers/》] [accessed 28.02.17].

[11] French MJ. On the difficulty of inventing an economical sea wave energy converter: a personal view. Proc. IMechE., Part M: J. Engineering for the Maritime Environment 2006; 220: 149-155.

[12] AeroVironment, Marine Energy Systems [online]. Available: 〈http://www.avinc.com/innovative-solutions/clean-energy-water $\rangle ;$ [accessed 28.02.17].

[13] Salter SH. Wave Power. Nature 1974; 249: 720-724.

[14] Aggidis GA. \& Taylor CJ. Overview of wave energy converter devices and the development of a new multi-axis laboratory prototype. Proceedings of the International Federation of Automatic Control 20th Triennial World Congress, Toulouse, France; 2017. (In Press)

[15] Jeans TL, Fagley C, Siegel SG \& Seidel J. Irregular deep ocean waves energy attenuation using a cycloidal wave energy-converter. International Journal of Marine Energy 2013; 1:16-32.

[16] Sogeti-Hightech, Sea Heart Convertor [online]. Available: 《https://www.sogeti-hightech.fr/en/sea-heart-convertor/ 》); [accessed 28.02.17].

[17] Akimoto H \& Tanaka K. Conceptual study of a drag type water turbine for electricity generation from wave power. In: Proceedings of the 12th international symposium on fluid control, measurement and visualization, Nara, Japan; 2013.

[18] Falcão AFO, Gato LMC \& Nunes EPAS. A novel radial self-rectifying air turbine for use in wave energy converters. Renewable Energy 2013; 53: $159-164$

[19] Pirisi A, Mussetta M, Gruosso G \& Zich RE. Optimization of a linear generator for sea-wave energy conversion by means of a hybrid evolutionary algorithm. In: Proceedings of the IEEE world congress on computational intelligence, Barcelona, Spain; 2010: 3600-3605.

[20] Schmittn P \& Elsaesser B. On the use of OpenFOAM to model oscillating wave surge converters. Ocean Engineering 2015; 108: 98 104.

[21] Noad IF \& Porter R. Optimisation of arrays of flap type oscillating wave surge converters. Applied Ocean Research 2015; 50: 237-253. 
[22] Orer G. \& Ozdamar A. An experimental study on the efficiency of the submerged plate wave energy converter. Renewable Energy 2007; 32:1317-1327.

[23] Cerveira F, Fonseca N \& Pascoal R. Mooring system influence on the efficiency of wave energy converters. International Journal of Marine Energy 2013; 3: 65-81.

[24] Honey KT \& Pagani GA. Bio inspired energy: Biomimicry innovations for energy sustainability [online]. Available: 《http:// madeinhaus.s3.amazonaws.com/sficom/staging/uploads/ckeditor/2016/11/02/bioenergyandreakristenrevise d 10-06-2013.pdf $\rangle$ [accessed 28.02.17].

[25] Zheng YJ, Chen SY, Lin Y \& Wang WL. Bio-inspired optimization of sustainable energy systems: a review. Mathematical Problems in Engineering 2013; 1-12.

[26] BPS, bioWAVE [online]. Available: 《 http://bps.energy/biowave 》; [accessed 28.02.17].

[27] Phys.org, Kelp [online]. Available: 〈〈http://cdn.phys.org/newman/gfx/news/hires/2014/researchersl.jpg》 [accessed 28.02.17]

[28] Heart [online]. Available: 〈https://en.wikipedia.org/wiki/Heart》 [accessed 28.02.17]

[29] Ecomerit Technologies, Centipod [online]. Available: 《http://www.ecomerittech.com/centipod.php》〉 [accessed 28.02.17].

[30] Vgmuseum, Centipod [online]. Available: 《http://www.vgmuseum.com/mrp/multi/Essays/enemieskev/centipod.jpg $\rangle$ [accessed 28.02.17].

[31] Wave Dragon, Wave Dragon [online]. Available: $\langle$ http://www.wavedragon.net/》〉; [accessed 28.02.17].

[32] Pinterest, Dragon [online]. 《https://uk.pinterest.com/pin/527554543820315845/》》 28.02.17].

[33] Aqua Marina Power, Sustainable Energy [online]. Available: 《http://www.aquamarinepower.com/》》; [accessed 28.02.17]

[34] Associated Newspapers Ltd, Oyster [online]. Available: 《http://www.dailymail.co.uk/sciencetech/article-1301903/Interactivemap-new-look-secret-life-Britains-seas.html $\rangle$ [accessed 28.02.17].

[35] Praneetsamaiya, Ant Colony Optimization [online]. Available: 《http://praneetsamaiya.blogspot.co.uk 〉 [accessed 28.02.17].

[36] Tethys, Wave [online]. Available: 《https://tethys.pnnl.gov/technologytype/wave) [accessed 28.02.17].

[37] McCall A \& Fleming A. Advanced Controls for the Multi-pod Centipod WEC device. Dehlsen Associates, LLC, Santa Barbara, CA and U.S. Department of Energy, Washington, DC. 2016 [online]. Available: 《https://www.osti.gov/scitech/biblio/1237967/》》 [accessed 28.02.17].

[38] Soerensen HC \& Madsen EF. Christensen L, et al. The results of two years testing in real sea of wave dragon. In: Proceedings of the 6th European wave and tidal energy conference, Glasgow, UK; 2005:481488 .

[39] Baike, Oyster [online]. Available: 〈http://www.baike.com/wiki/\%E7\%89\%A1\%E8\%9B\%8E/》〉 [accessed 28.02.17].

[40] Drew B, Plummer AR \& Sahinkaya MN. A review of wave energy converter technology. In: Proceedings of the Institution of Mechanical Engineers, Part A: Journal of Power and Energy 2009; 223:887-902.

[41] Whittaker T \& Folley M. Nearshore oscillating wave surge converters and the development of Oyster. Philos. Trans. R. Soc. 2012; 370: 345364.

[42] Colorni A, Dorigo M \& Maniezzo V. Distributed optimization by an colonies. In: Proceedings of European conference on artificial life, Paris, France; 1991: 134-142.

[43] See PC, Tai VC \& Molinas M. Ant colony optimization applied to control of ocean wave energy converters. Energy Procedia 2012; 20: 148-155.

[44] Baike, Pelamis [online]. Available: 〈http://www.baike.com/wiki/\%E6\%B5\%B7\%E8\%9B\%87》》 [accessed 28.02.17].

[45] Wordpress, Pelamis-wave-power [online]. Available: 〈https://mendocoastcurrent.wordpress.com/tag/pelamis-wave-power/》》 [accessed 28.02.17].

[46] Kidzone, Anaconda [online]. Available: $\langle$ http://www.kidzone.ws/lw/snakes/facts-anaconda.htm》》 [accessed 28.02.17]

[47] Dreamstime, Human Circulatory System [online]. Available: «https://www.dreamstime.com/stock-images-blood-flow-human- circulatory-system-illustration-white-background-image35501514〉 [accessed 28.02.17]

[48] Checkmate Sea Energy, Anaconda [online]. Available: $\langle$ http://www.checkmateukseaenergy.com/anaconda/》》 [accessed 28.02.17]

[49] Wikipedia, Pelamis Wave Power [online]. Available: 〈https://en.wikipedia.org/wiki/ Pelamis_Wave_Power》》 [accessed 28.02.17].

[50] Chaplin JR, Heller V \& Farley FJM, Hearn GE. Laboratory testing the Anaconda. Phil. Trans. R. Soc. 2012; 370: 403-424.

[51] Agrawal R, Imilienski T \& Swami A. Mining association rules between sets of items in large databases. In: Proc. of the ACM SIGMOD Int'1 Conference on Management of Data, Washington DC, USA; 1993:207216.

[52] Heller, Case study Anaconda [online]. Available: $\langle\langle$ https://www.researchgate.net/publication/280655723》》_ [accessed 28.02.17]

[53] Heller V, Chaplin J, Farley F, Hann M, Hearn G. Physical model tests of the wave energy converter Anaconda. In: Proceedings of the 1st European Conference of IAHR, Edinburgh, UK; 2010:1-6.

[54] Joubert J, Niekerk J, Reinecke J, Meyer I. Wave Energy Converters (WECs). Centre for Renewable and Sustainable Energy Studies.2013.

[55] Penguin [online]. Available: 《http://www.emec.org.uk/about-us/waveclients/wello-oy/ $\rangle \_[\text {accessed 28.02.17]. }$

[56] Penguin [online]. Available: 〈http://www.wello.eu/en/fi 》 [accessed 28.02.17].

[57] Falcão A, Henriques H. Oscillating-water-column wave energy converters and air turbines: A review. Renewable Energy. 2016; 85: 1391-1424.

[58] Osprey, Renewable Energy [online]. Available: 〈/http://www.ospreyltd.com/renewable_energy 》_[accessed 28.02.17].

[59] TW Thorpe, A Brief Review of Wave Energy [online]. Available: 《 http://lamtengchoy.com/main/uploads/others/1298524568_8914.pdf)》 [accessed 28.02.17].

[60] Wavegen [online]. Available: 《http://www.wavegen.com》》 [accessed 28.02.17].

[61] Jessica J. The Global ocean energy picture. Ocean Yearbook Online 2008; 22(1): 323-351.

[62] Heath T, Whittaker T, Boake C. The design, construction and operation of the LIMPET wave energy converter (Islay, Scotland). In: Proceedings of the 4th European wave energy conference. Aalborg, Denmark; 2000

[63] Voith Hydro Wavegen Limited [online]. Available: 《http://www.wavegen.co.uk/what_we_offer_limpet.htm》 [accessed 28.02.17].

[64] Hotta H, Washio Y, Yokozawa H, Miyazaki T. R\&D on wave power device "Mighty Whale". WREC 1996; 1223-1226.

[65] Washio Y, Osawa H, NagataY, Fujii F, Furuyama H and Fujita T. The offshore floating type wave power device "Mighty Whale": Open sea tests," In: Proceedings of the 10th International Offshore and Polar Engineering Conference (ISOPE '00), Seattle, Wash, USA; 2000: 373 380 .

[66] Marine Technology Department, JAMSTEC, Mighty Whale [online]. Available: 《http://www.takesteps.org/empower/exhibition/B1b3_d2_12_c4_Mighty\%20Whale_wave-power.html 》 [accessed 28.02.17].

[67] Kofoed J, Frigaard P, Friis-Madsen E, Sørensen HC. Prototype testing of the wave energy converter wave dragon. Renew energy. 2006; 31 : 181-189.

[68] Renzi E, Doherty K, Henry A, Dias F. How does Oyster work? The simple interpretation of Oyster mathematics. European Journal of Mechanics B/Fluids. 2014; 47: 124-131.

[69] Folley M, Whittaker TJT, Hoff J. The design of small seabed-mounted bottom-hinged wave energy converters. In: Proceedings of 7th European Wave Tidal Energy Conference, 2007.

[70] Bio Power Systems [online]. Available: 《http://www.biopowersystems.com/technologies.php》》 [accessed 28.02.17].

[71] Gonzalez CA, Kloos G, Finnigan T. Development of a multi-bladed $250 \mathrm{~kW}$ pitching wave-energy converter. In: proceedings of the 8th European wave and tidal energy conference, Uppsala, Sweden; 2009:410-415

[72] James GP. Wave energy converter system. US Patent US9074577, 2013.

[73] Edinburgh Wave Power Group, Salter Duck [online]. Available: 〈http://www.mech.ed.ac.uk/research/wave power》》 [accessed 28.02.17] 
[74] Retzler, C. Measurements of the slow drift dynamics of a model Pelamis wave energy converter. Renewable Energy. 31, 257-269(2006)

[75] Pelamis wave power [online]. Available: 〈http://www.pelamiswave.com/》 [accessed 28.02.17]

[76] Duck [online]. Available: 《http://english.giec.cas.cn/rh/rp/201304/t20130428_101448.html》》 [accessed 28.02.17].

[77] Eagle [online]. Available: 《http:// www.tynxb.org.cn/UserFiles/File/paibanshili.doc) [accessed 28.02.17].

[78] Sheng SW, Zhang YQ, Wang KL, Lin HJ, Wang WS, Chen AJ. The overall design of wave energy convertor WanShan, Ship Engineering. 2015; 37: 10-14.

[79] Squid [online]. Available: 《http://WaveNET\How WaveNET Works Albatern.html $\rangle$ [accessed 28.02.17].

[80] Squid [online].Available: 《 http://londonresearchinternational.com/wpcontent/uploads/2014/07/Albatern-Newsletter.pdf $\rangle$ [accessed 28.02.17]

[81] Seaweed [online].Available:

https://www.greyislandenergy.com/seaweed-technology $) \quad$ [accessed 28.02.17]

[82] Jellyfish [online].Available: 《http://oscillapower.com/triton-wec/ $\rangle$ [accessed 28.02.17].

[83] Jellyfish [online].Available: 《http://trendintech.com/2016/05/01/thismechanical-jellyfish-harvests-tons-of-energy-from-the-ocean/ $/\rangle$ [accessed 28.02.17].

[84] Hibbs BD, Tyler MC, Tokumaru P, Zambrano T. Method of and apparatus for wave energy conversion using a float with excess buoyancy. US006756695B2, 2001

[85] Zanuttigh B, Angelelli E, Bellotti G, Romano A, Krontira Y, Troianos D, Suffredini R, Franceschi G, Cantù M, Airoldi L, Zagonari F, Taramelli A, Filipponi F, Jimenez C, Evriviadou M and Broszeit S. Boosting blue growth in a mild sea analysis of the synergies produced by a multi-purpose offshore installation in the Northern Adriatic, Italy, Sustainability. 2015; 7(6): 6804-6853.

[86] Wave Star Energy. [online].Available: 〈http://wavestarenergy.com/ $\rangle$ [accessed 28.02.17].

[87] McCabe AP, Bradshaw A, Meadowcroft JA, Aggidis G. Developments in the design of the PS Frog Mk 5 wave energy converter, Renewable Energy. 2006; 31: 141-151.

[88] SEADOG, Pump Technology Wave Energy Converter. [online]. Available:

《http://www.isope.org/publications/proceedings/ISOPE/ISOPE\%20200 6/papers/2006_CSS_01.pdf 〉 [accessed 28.02.17].

[89] SEADOG [online]. Available: [54]http://inri.us/index.php/SEADOG) $\rangle$ [accessed 28.02.17].

[90] Heath T, Whittaker $\mathrm{T}$ and Boake C. Research into the further development of the limpet shoreline wave energy plant, DTI Sustainable Energy Programmes, Boulder, CO, ETSU V/06/00183/ REP, 2002.

[91] Fadaeenejad M, Shamsipour R, Rokni SD, Gomes C. New approaches in harnessing wave energy with special attention to small islands, Renewable and Sustainable Energy Reviews. 2014; 29: 345-354.

[92] Yemm R, Pizer D, Retzler C and Henderson R. Pelamis: experience from concept to connection, Philosophical Transactions: Mathematical, Physical and Engineering Sciences. 2012; 370 (1959):365-380.

[93] Yemm RW, Henderson RM, Taylor CAE. The OPD Pelamis WEC current status and onward programme. In: Proceedings of fourth European wave energy conference, Aalborg, Denmark; 2000:104-109. 